\title{
COVID-19 as an Opportunity for a Healthy-Sustainable Food Transition. An Analysis of Dietary Transformations during the First Italian Lockdown
}

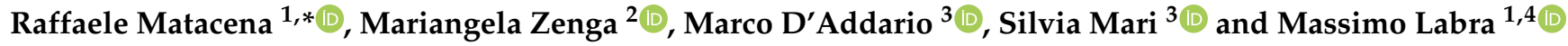 \\ 1 BEST4Food-Bicocca Center of Science and Technology for Food, University of Milan-Bicocca, \\ 20126 Milan, Italy; massimo.labra@unimib.it \\ 2 Department of Statistics and Quantitative Methods, University of Milan-Bicocca, 20126 Milan, Italy; \\ mariangela.zenga@unimib.it \\ 3 Department of Psychology, University of Milan-Bicocca, 20126 Milan, Italy; marco.daddario@unimib.it (M.D.); \\ silvia.mari@unimib.it (S.M.) \\ 4 Department of Biotechnologies and Biosciences, University of Milan-Bicocca, 20126 Milan, Italy \\ * Correspondence: raffaele.matacena@unimib.it
}

check for updates

Citation: Matacena, R.; Zenga, M.; D'Addario, M.; Mari, S.; Labra, M. COVID-19 as an Opportunity for a Healthy-Sustainable Food Transition. An Analysis of Dietary Transformations during the First Italian Lockdown. Sustainability 2021, 13, 5661. https://doi.org/10.3390/ su13105661

Academic Editor: Stefan Hoffmann

Received: 17 February 2021

Accepted: 11 May 2021

Published: 18 May 2021

Publisher's Note: MDPI stays neutral with regard to jurisdictional claims in published maps and institutional affiliations.

Copyright: (c) 2021 by the authors. Licensee MDPI, Basel, Switzerland. This article is an open access article distributed under the terms and conditions of the Creative Commons Attribution (CC BY) license (https:// creativecommons.org/licenses/by/ $4.0 /)$.

\begin{abstract}
The COVID-19 emergency and the consequent social distancing requirements have caused major disruptions in daily food-related practices at the household level. In this paper, we evaluate the transformations that occurred in the daily nutritional choices and behaviors of a convenience sample ( $n=2288$ ) of Italian residents during the first nation-wide lockdown (March-May 2020) to assess the impact on the health and socio-environmental sustainability of their diets. Results portray a scenario of wide-spread change, especially in relation to the quantity of daily food consumed, the composition of diets and the time and commitment devoted to home-cooking, with young individuals emerging as the most impacted generational cohort. Through the construction of an indicator for healthy-sustainable transition (HST index), we demonstrate that such changes unfold on a gradient, revealing that while for many respondents lockdown nutrition implied overeating and weight gain, a substantial segment of the population conversely improved the healthiness and sustainability of their daily nutritional patterns. In this sense, improvements are associated with young age, socio-economic status, frequency and enjoyment of cooking-from-scratch and, more generally, an attentive attitude towards the quality, provenance and materiality of food that, in turn, the COVID-19 crisis appears to have re-kindled. We conclude by highlighting five areas of institutional intervention (i.e., young people, time, tools, food supply at work, and local food chains) on which to focus in order to ensure the current crisis does not represent a missed opportunity for creating the necessary conditions for sustainable food production and consumption to take hold as the 'new' normal in the post-pandemic era.
\end{abstract}

Keywords: COVID-19; lockdown; healthy-sustainable diets; food-related behaviors; nutrition; Italy

\section{Introduction}

The COVID-19 crisis has been exerting enormous pressure on the daily life of individuals. At the moment of writing-approximately one year into the pandemic-health concerns, social distancing measures, and activity shutdowns have become familiar components of the daily lives of billions of people. The pandemic abruptly-and deeply, in many cases-altered the life and working habits of societies all over the world. Concurrently, the outbreak of the global emergency provided worldwide exposure to the nexus that links human health with environmental degradation, bringing the unsustainability inherent in current production, consumption, and global trade models to center stage. Within this critical scenario, nutrition occupies a central position [1] for its relevance as a daily life practice and its deeply rooted entanglements with issues of individual health and planetary socio-environmental sustainability. 
Since the introduction of lockdown measures, which embody a radical modification of consolidated routines, food has been put under the spotlight for the crucial role it plays in the daily life of people in countries struck by the diffusion of the virus. Anecdotal and journalistic evidence has invariably underscored that individuals enduring mandatory confinement and social distancing have diffusely adopted food and nutrition as one of the cornerstones upon which to build 'new' (forced) daily life arrangements. During lockdown days, an unprecedented amount of time and consideration has indeed been devoted to the activities and behaviors related to nutrition-concretized in the acts of purchasing, cooking and consuming food. In a context in which working-day away-from-home and school meals were no longer available, and the operations of the food service sector were significantly reduced, people found themselves forced to prepare (the vast majority of) and consume (all of) their meals at home. However, a host of evidence-from market research reports [2] to journalistic and social media sources [3] — points out that in many instances food preparation has actually represented an element of leisure, being adopted as a hobby to fill the sudden increase in free time caused by confinement.

In addition, the disruption of daily routines, together with the impossibility of performing customary activities, has been vastly perceived as a threat to individual and familial well-being, likely to produce negative psychological effects, such as feelings of boredom, confusion, anxiety, stress, anger and/or depression [4,5]. In this sense, food has also taken on a 'comforting' role, intended to alleviate negative emotional conditions and compensate for the (perceived) loss of well-being [6,7]. Here, though, significant health implications may arise. Many authors are compelled by the risk ascribed to excessive or unbalanced eating in quarantine, which when combined with a more sedentary lifestyle and a reduced level of physical activity, can lead to weight gain and other negative health repercussions [5,8-11]. As a consequence, whether food increased its value as a 'hobby' or as a mechanism to cope with emotional distress, scrutinizing the health outcomes of lockdown diets appears crucially important.

More broadly, as an effect of the global sanitary crisis, the diet-health nexus appears more exposed than ever. Recent studies have been pointing out that nutritional status is a relevant factor influencing the outcome of patients with COVID-19 [12,13], warning that subjects affected by metabolic diseases are more prone to develop severe illness [14,15]. Oppositely, research has highlighted the potential of diets to benefit the immune system and subsequently decrease disease susceptibility [12]. Under the siege of a global disease, then, the discourse on healthy diets becomes centerpiece. In fact, the notion of a healthy and varied nutritional regime becomes not only the basis for a key recommendation from the perspective of public health prevention, but also finds its way into the interests of the general population, arguably more attentive than ever to issues of health self-management.

Parallel to the issue of health, and strongly interrelated with it, scientific concerns regarding food and nutrition in the COVID-19 era are tied to the discourse about sustainability. They lean on a twofold, intertwined, argument. On the one hand, there is growing awareness of the impossibility of following a truly healthy diet without it also being a sustainable diet. On the other, from a wider standpoint, the pandemic is considered a vivid demonstration of the unsustainability of our social and economic systems. As most of the infectious diseases that have emerged in humans since the 1940s [16], COVID19 has a zoonotic origin [17], and the global intensive production system on which our food economy is based ought to be considered a major driver of animal-to-human virus spillover $[18,19]$. The efficiency imperative that dominates global food trade and the associated industrial agricultural and urbanization development models increasingly prompt the destruction of ecological and cultural biodiversity, which in turn facilitates spillover and human-to-human pathogen transmission processes [13,20].

In order to reform the present production-consumption paradigm, then, one of the most urgent challenges facing humanity lies in addressing the unsustainability inherent in the world's current dietary patterns. In 2019, the FAO described sustainable diets as those nutritional regimes that promote all dimensions of individuals' health and well- 
being, while, concurrently, having low environmental impact, and being affordable, safe, equitable and culturally acceptable [21]. What this definition reflects is the consensus within the scientific community about the inadequacy of conceiving a healthy diet as an exclusively individual-centric notion, i.e., without recognizing its relationship with the external (economic, social, and cultural) elements that bridge the individual with food [22] Thus, the sustainability of diets is increasingly seen not as an effect of a sustainable food system, but rather as an essential means to construct a sustainable food system [23-25].

In this light, the lockdown represents an unprecedented opportunity not only to monitor the propensity of individuals to realize more or less healthy and sustainable food choices given the abruptly changed circumstances, but also to advance preliminary considerations about what can be done to channel positive transformations.

Although the long-lasting effects of the pandemic are uncertain, a host of observers see the whole COVID-19 global experience as a massive wake-up call to implement muchneeded corrections to the current (unsustainable) development model [26-32]. The physicist Fritjof Capra described coronavirus as "a biological response of [our planet] to the ecological and social emergency humanity has brought upon itself" [33]. The pandemic outbreak, indeed, laid bare the critical weaknesses, inequalities and inequities of an impressively large set of human systems, the extent and severity of which are strongly linked to all three dimensions of unsustainability. As already noted, ecological unsustainability is addressed as the culprit of initial viral transmission, but the violence of the impacts of the pandemic and the difficulties of handling the crisis are dependent on the economic and social paradigm governing our globalized society. As powerfully summarized by Bodenheimer and Leidenberger [34], it is a "lack of ecological sustainability [that] contributed to the coronavirus outbreak, lack of economic sustainability to its rapid and global spread, and lack of social sustainability to its severity".

Finally, the resilience of our society, i.e., the capacity to truly recover from the daily life 'disruptions' caused by the pandemic, will be tested against our ability to challenge the very roots of the unsustainability of modern life. It requires re-thinking the organizational model upon which our social and economic lives are based, to lead the way to a new societal paradigm more attuned to the human and natural components of our existence on the planet. Now more than ever we-as citizens-need to take into consideration the sustainability of each one of our actions, if we want the process of recovery from COVID-19 to proceed under the banner of 'transformative resilience' [35], that is, the capacity of the individual, the society and the economic system to 'bounce forward' rather than back to where we were a few months ago. In this sense, daily food habits, for their societal relevance and for the critical impact of food chains on global sustainability, are a privileged starting point.

It is against this backdrop that the study presented in the rest of this paper is positioned, and to which it offers its contribution. The study is part of ongoing research that analyzes the effects of the pandemic on the healthiness and sustainability of food-related behaviors. It does so by means of an empirical investigation carried out in Italy, one of the first countries to be severely hit by the COVID-19 pandemic. The study is presented as follows: Section 2 introduces the research, positing its aims within the frame of currently available literature. Section 3 details the methods and statistical tools employed for the investigation. Section 4 presents the results and Section 5 discusses them. Section 6 concludes the paper.

\section{Research Aims and Background}

In 2020 the BEST4Food interdepartmental center of the University of Milano-Bicocca (Milan, Italy) launched a study to investigate the psychological, social and sustainabilityrelated aspects of individuals' food-related behaviors during the emergency period linked to the COVID-19 pandemic in Italy. The general aim was to understand what lessons could be drawn from the spontaneous (yet circumstantially 'forced') reaction of individuals to the COVID-19 crisis, in order to contribute to the discourse on how to design and implement a post-pandemic food system able to provide health, well-being and sustainability. The 
first stage of the project focused on the change in food-related behaviors that followed the imposition of the first nation-wide lockdown (March-May 2020), which required all individuals to follow strict isolation and social distancing guidelines.

A few months into the pandemic, a host of timely empirical research conducted in different countries had already contributed to describing a picture of fast and widespread transformations of individual food-related behaviors. Most studies, however, addressed lockdown eating from a nutritional sciences perspective [36]. Some of these studies depicted a scenario of generalized nutritional impoverishment [37,38], whereas others detected a diversified range of impacts, reflecting distinct (and often opposite) effects of the lockdown on nutrition [10,39]. Another strand of work, instead, testified to the disruptions in household food consumption from a standpoint grounded in social sciences [40,41]. To the best of our knowledge, then, there is a paucity of empirical investigations that examine both the health and sustainability outcomes of lockdown-induced food transformations, blending social, nutritional and environmental perspectives. One exception is represented by Batlle-Bayer et al. [42], who also performed an analysis of the environmental impacts of lockdown diets. What differentiates their work, however, is that they produced their estimates employing secondary data.

With the aim of filling this gap, we carried out a survey during the Italian lockdown, under the hypothesis that behavioral and attitudinal patterns related to buying, preparing and consuming food had undergone substantial changes with respect to the established habits of 'ordinary' periods. The specific objective, thus, was to verify such hypothesized transformations and link them to social, environmental and economic sustainability, as well as to the psychological, emotional and physiological well-being of individuals.

In this paper we will address the issue of diets. We will provide an overview of households' eating and cooking patterns during the lockdown to highlight the extent of their transformation, and make use of a statistical tool, the healthy-sustainable transition (HST) index, to answer the following research questions:

(a). What are the impacts of lockdown-induced daily life re-arrangements on the healthiness and sustainability of nutrition?

(b). Are there factors underlying a transition towards a more healthy-sustainable (HS) diet during the lockdown, which could be leveraged to foster a systemic HS transition?

\section{Methods}

The data collection method chosen consisted of an online survey administered to 3630 Italian residents from May to June 2020, employing Qualtrics software (Qualtrics, Version April 2020; Qualtrics, Provo, UT, USA). Participants were recruited using an online link posted on official communication channels of the university (webpage, newsletter and social media) and through snowball personal communications of the researchers involved. Ultimately, the sample was a convenience sample. Despite the disadvantages of this kind of non-probability sampling, convenience sampling lends itself to some important uses, especially in the early stages of research investigating a novel ground or nascent phenomenon [43]. In our case, convenience sampling served the purpose of capturing attitudes and opinions and identifying some tentative hypotheses on a new topic such as the relations among food practices in the immediate aftermath of the COVID-19 pandemic outbreak. It also allowed researchers to work around the time and mobility constraints imposed by the emergency situation. Finally, eating and food procurement being basic activities undertaken by all individuals, the method proved useful in providing a basis for interpreting emerging relations that, in a subsequent step of the study, will be tested more rigorously using probability samples.

The survey recorded 2288 complete responses, with a median duration of $18 \mathrm{~min}$ (5-th percentile: $9.62 \mathrm{~min}$; 95-th percentile: $49.37 \mathrm{~min}$ ). Such a high response rate is to be attributed to the methodological approach taken. The questionnaire was designed to link data about socio-demographics and living conditions (first section, 14 items) with self-reported changes in practices related to food consumption (second section, 33 items), 
cooking (third section, 8 items) and food shopping (fifth section, 23 items). The last three sections recorded information about psychological condition during the lockdown (21 items), weight management, physical activity, and health status (7 items), and lastly, food- and sustainability-related opinions, attitudes, and future intentions (18 items).

\subsection{Description of the Sample}

Of the 2288 complete responses recorded, $73.1 \%$ were provided by participants who identify as females. A majority of respondents (56.7\%) were under 40 years old (average age was 38.59 years, S.D. 14.08). Most respondents (82.2\%) lived in Northern Italy (67.9\% in Lombardy, the region most affected by COVID-19) and spent the lockdown with their families (88.3\%). Among the latter, $32.5 \%$ of households consisted of just a couple, $24.3 \%$ of three people, and in $31.5 \%$ of cases households comprised four or more people. The individuals who spent the period alone represented $11.7 \%$ of the sample.

The educational level of the sample is imbalanced towards higher educational attainments: $67.2 \%$ of respondents in fact hold either a graduate or a post-graduate degree. Perhaps relatedly, the sample is characterized by higher-than-average levels of socioeconomic status, which has been measured in its subjectively perceived form employing the MacArthur Scale of Subjective Social Status. This is a pictorial measure represented by a 10-rung social ladder on which participants were asked to indicate their socioeconomic standing relative to others in society based on income, educational level and occupation [44]. With a mean value of 6.12 (S.D. 1.37) our sample reported a relatively high level of subjective welfare. Nevertheless, a large proportion of respondents $(38.6 \%)$ lamented a worsening effect of the COVID-19 emergency on their economic conditions, either severe or moderate.

As per the working conditions during the lockdown, $59.8 \%$ of the sample reported having worked from home, while $11.6 \%$ declared not having worked at all in the period, either due to forced leave or job loss. The survey also included people who are employed in essential sectors and therefore carried on with their usual occupations (8\%). The remainder (20.8\%) was composed of students, retired people, and other unspecified categories. Table 1 reports the socio-demographic profile of the sample in detail.

\subsection{The Healthy-Sustainable Transition Index}

Dietary healthiness and sustainability are two extremely interdependent elements that must be considered a systemic dyad, and therefore measured, analyzed and promoted in conjunction [24]. Hence, in order to examine the 'lockdown effect' on diet composition we included a 'food frequency' question (the aggregated results of which are shown in Table 5, Section 4.1.) in the survey, composed of eleven items, namely: carb-based dishes; meat; vegetables; legumes; whole-grain cereals; nuts and oily seeds; dairy products; sweets and desserts; fresh fruit; sugary beverages; and alcoholic beverages. The items were adapted from the EATLancet Commission's guidelines for a planetary healthy-sustainable diet [24]. Drawing on this data, we constructed the healthy-sustainable transition (HST) index, a synthetic tool that provides an aggregate score for respondents' dietary transformations, signaling whether and to what degree they represent a transition towards a more or less healthy-sustainable consumption model.

Aiming to obtain a summary of respondents' answers and examine the component structure of a latent construct underlying food frequency results, we reduced the dimensionality of the data by identifying one or more subscales (or factors) that summarize the available variables. Since the question had ordered categorical items, we applied a categorical principal component analysis (CatPCA) [45]. In CatPCA, the categories of variables are assigned numeric values through a process called optimal scaling [46,47], which transforms categories of variables with ordinal levels into numeric value variables that are referred to as category quantifications. Optimal scaling replaces the category labels with category quantifications in such a way that as much as possible of the variance in the quantified variables is accounted for [46]. The evaluation of goodness of fit is based on 
the total variance accounted for in the transformed variables (VAF), on its corresponding percentage (PVAF), and on a generalized version of Cronbach's alpha [48,49]. To proceed with the CatPCA, the original categories of the food frequency items-which were: Never (neither before nor during the lockdown); Less frequently than before; As usual; More frequently than before (see Table 5 in Section 4.1)—were collapsed into three categories as follows: Less than before; Never or equal to before; More than before. The second category is thought to underline behaviors that have not changed since before the lockdown.

Table 1. Distribution of the sample by socio-demographic and housing variables.

\begin{tabular}{|c|c|c|}
\hline & $N$ & $\%$ (Sample) \\
\hline \multicolumn{3}{|l|}{ Gender } \\
\hline Male & 613 & 26.8 \\
\hline Female & 1672 & 73.1 \\
\hline Other identity & 3 & 0.1 \\
\hline \multicolumn{3}{|l|}{ Generational cohort } \\
\hline Gen Z (14-24) & 433 & 18.9 \\
\hline Young Millennials (25-29) & 348 & 15.2 \\
\hline Adult Millennials (30-40) & 570 & 24.9 \\
\hline Gen X $(41-55)$ & 604 & 26.5 \\
\hline Baby Boomers (56-76) & 321 & 14.0 \\
\hline Elderly (over 77) & 12 & 0.5 \\
\hline \multicolumn{3}{|l|}{ Place of residency } \\
\hline Lombardy region & 1553 & 67.9 \\
\hline Other regions in Northern Italy & 342 & 14.9 \\
\hline Central Italy & 139 & 6.1 \\
\hline Southern Italy & 254 & 11.1 \\
\hline \multicolumn{3}{|l|}{ Educational attainment } \\
\hline Primary & 81 & 3.5 \\
\hline Secondary & 670 & 29.3 \\
\hline Graduate & 973 & 42.5 \\
\hline Post-graduate & 564 & 24.7 \\
\hline \multicolumn{3}{|l|}{$\begin{array}{c}\text { Subjective social status } \\
\text { (MacArthur scale from } 1 \text { to 10) }\end{array}$} \\
\hline 4 or less & 257 & 11.3 \\
\hline 5 & 415 & 18.2 \\
\hline 6 & 595 & 26.1 \\
\hline 7 & 720 & 31.6 \\
\hline 8 or more & 292 & 12.8 \\
\hline \multicolumn{3}{|l|}{$\begin{array}{l}\text { Effect of COVID-19 crisis on } \\
\text { household economic condition }\end{array}$} \\
\hline Strongly detrimental & 214 & 9.4 \\
\hline Slightly detrimental & 668 & 29.2 \\
\hline No effect & 1241 & 54.2 \\
\hline Slightly beneficial & 154 & 6.7 \\
\hline Strongly beneficial & 11 & 0.5 \\
\hline \multicolumn{3}{|l|}{ Working condition under lockdown } \\
\hline Working from home (always or most days) & 1369 & 59.8 \\
\hline Not working (on leave, unemployed, etc.) & 265 & 11.6 \\
\hline Essential sector (working as usual) & 183 & 8.0 \\
\hline Other (students, retired, or unspecified) & 471 & 20.6 \\
\hline \multicolumn{3}{|l|}{ Household composition (during lockdown) } \\
\hline Single & 263 & 11.7 \\
\hline Couple & 732 & 32.5 \\
\hline 3 people & 546 & 24.3 \\
\hline $4-5$ people & 660 & 29.3 \\
\hline 6 people or more & 49 & 2.2 \\
\hline
\end{tabular}

Following the EATLancet Commission's recommendations [24], we split the food groups in two: sustainable foods (vegetables-based dishes, legumes, whole grain cereals, 
nuts and seeds, fresh fruit) and unsustainable foods (carb-based dishes, meat-based dishes, dairy products, sweets and desserts, sugary beverages, alcohol); then we applied CatPCA on the two groups separately. We considered the first component on each group suitable for creating two separate indexes reflecting the changes in consumption of sustainable (CCSF) and non-sustainable (CCNSF) foods (for reasons of space, a detailed account of the two CatPCA procedures is omitted. Interested readers can request it from the authors). The correlation between CCSN and CCSNF was -0.106 , which underlines a negative, weak linear relationship between these two latent variables. Subsequently, in order to summarize the change in food choices in one single instrument, we used a PCA on CCSN and CCSNF, whose results are reported in Table 2 .

Table 2. PCA on the indexes of sustainable (CCSN) and not sustainable (CCSNF) food consumption.

\begin{tabular}{ccc}
\hline \multicolumn{3}{c}{ Results of PCA on CCSN and CCSNF } \\
\hline Dimension & Eigenvalues & \% Variance \\
\hline 1 & 1.188 & 59.402 \\
2 & 0.812 & 40.598 \\
\hline Total & 2 & 100 \\
\hline
\end{tabular}

The first component explains about $60 \%$ of the variability of the dimensions and has an eigenvalue greater than 1 , thus it can be considered a good summary of the two previous latent variables. Moreover, the component loading of the two variables with respect to the first dimension are 0.649 for CCSN and -0.649 for CCSNF. The new latent construct is therefore interpretable as an indicator of healthy-sustainable transition of dietary behavior (HST index), reflecting the overall changes that individual consumption patterns underwent as an effect of the first Italian lockdown: the more the value is positive, the more the change represents a transition towards healthier and more sustainable food choices; vice versa, the more the value is negative, the more the change represents a transition towards less healthy and sustainable food choices.

The distribution of the HST index in the sample is reported in Figure 1. As expected, it peaks around the zero value, where respondents who realized modest changes in terms of diet health and sustainability are allocated. Concurrently, it portrays a scenario of diffused transformation, where large segments of the population adopted a more HS diet, while others reduced the HS scope of their nutrition. A deeper analysis of the factors underlying a positive transition is delivered in the next section.

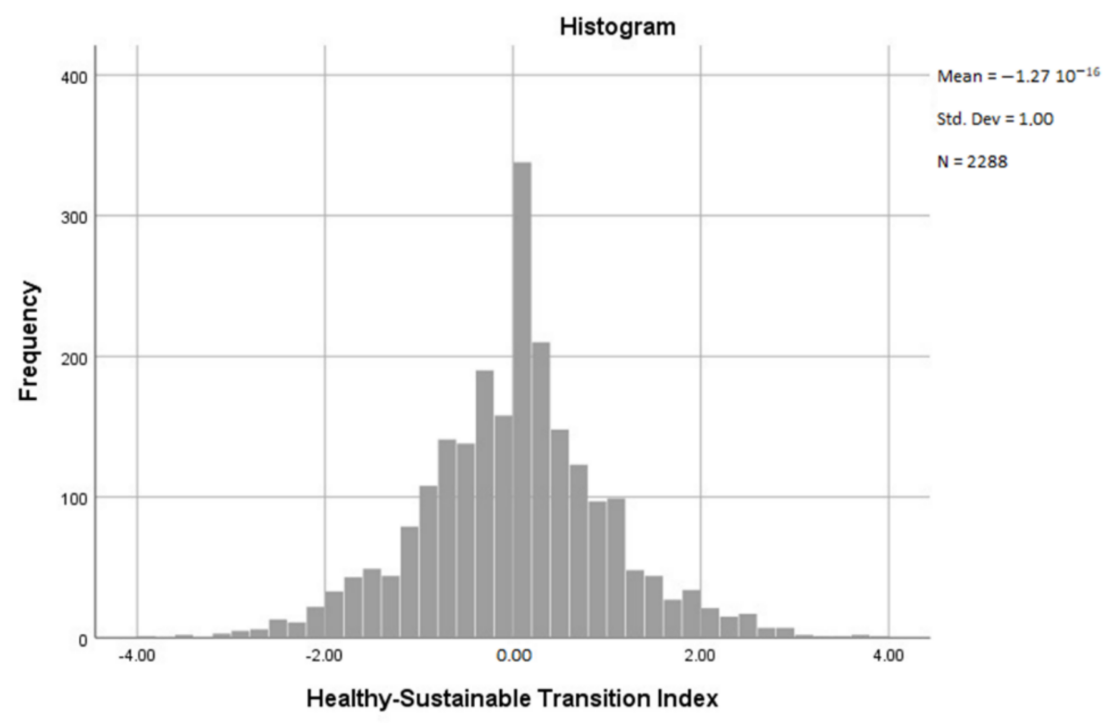

Figure 1. Distribution of the HST index scores in the sample. 


\section{Results}

As far as daily food habits are concerned, the results of the study signal that the lockdown measures have had three major effects: firstly, the diets of individuals, i.e., their daily nutritional patterns, have been significantly altered; secondly, while in social confinement, households have transformed their cooking habits; and thirdly, the segment of the population that appears to have born the largest consequences in terms of daily life disruption is that of young individuals, namely those belonging to generation Z (14-24) and young millennials (25-29). These cohorts, indeed, reported the biggest changes in most of the dimensions analyzed by the study. In other terms, if compared to other age groups, the food-related habits and behaviors of young people seem to have been more strongly affected by the lockdown.

\subsection{Dietary Habits}

During the lockdown, most individuals adopted a more varied diet, in comparison to the ordinary pre-COVID-19 period. In fact, as shown in the bottom row of Table 3, almost half $(48.3 \%)$ of the sample reported an increase in the variety of their diets whereas only $12.4 \%$ followed a more monotonous nutritional regime. This is a transversal result, characterizing all age groups and family compositions, even though lower-than-average values were recorded for baby boomers (respondents aged 56-76) and singles (individuals who spent the lockdown living alone). In addition, this trend seems to be associated with the occupation of the respondent: as displayed in Table 3, $60.8 \%$ of those who did not work during the lockdown (due to forced leave or for job loss) improved the variety of their diet, while this figure decreases to $48.4 \%$ among those who worked remotely, and further to $38.3 \%$ among those employed is essential sectors who worked outside of home during the whole period. Time allowance, therefore, appears to be a determining factor in enabling the transition toward a more diversified nutritional pattern.

Table 3. Impact of the lockdown on the variety of diets, shown by categories of working condition during the lockdown.

\begin{tabular}{|c|c|c|c|c|c|}
\hline \multirow[b]{2}{*}{ Working Condition under Lockdown } & & \multicolumn{4}{|c|}{ Change in Diet Variety during the Lockdown } \\
\hline & & More Monotonous Diet & Same Variety as Usual & More Varied Diet & Total \\
\hline Working from home (always or most days) & Count & 170 & 536 & 663 & 1369 \\
\hline & Count & 32 & $\frac{39.2 \%}{72}$ & $\begin{array}{c}48.4 \% \\
161\end{array}$ & $\frac{100 \%}{265}$ \\
\hline Not working (on leave, unemployed, etc.) & $\%$ & $12.1 \%$ & $27.2 \%$ & $60.8 \%$ & $100 \%$ \\
\hline Essential sector (working as usual) & Count & 19 & $\begin{array}{c}94 \\
514 \%\end{array}$ & $\begin{array}{c}70 \\
383 \%\end{array}$ & 183 \\
\hline & Count & 63 & 198 & 210 & 471 \\
\hline Other (students, retired, or unspecified) & $\%$ & $13.4 \%$ & $42,0 \%$ & $44.6 \%$ & $100 \%$ \\
\hline Total & $\begin{array}{c}\text { Count } \\
\%\end{array}$ & $\begin{array}{c}284 \\
12.4 \%\end{array}$ & $\begin{array}{c}900 \\
39.3 \%\end{array}$ & $\begin{array}{c}1104 \\
48.3 \%\end{array}$ & $\begin{array}{c}2288 \\
100 \%\end{array}$ \\
\hline
\end{tabular}

Chi-squared test results: $\chi^{2}=32.27 ; p$-value $<0.0001$.

In conjunction with variety, lockdown diets were characterized by an increase in the overall quantity of food consumed. In fact, the marginal row of Table 4 shows how a large proportion of our sample (37.8\%) declared having amplified the magnitude of their daily food intake during the lockdown, in juxtaposition to the usual amounts consumed in their ordinary lives. Conversely, lighter-than-usual diets, in terms of quantities consumed, were adopted by just a minority of respondents (16.2\%). Similar to the datum about variety, and likely interrelated with it, this finding invests most socio-demographic segments in a single fashion. Yet, an even more substantial increase is associated with the condition of not having worked during the period ( $44.9 \%$ vs an average of $37.8 \%)$, whereas significant reductions in food quantity appear to be related to individuals living as singles ( $27 \%$ against a mean value of $16.2 \%$ ). Concurrently, bivariate analysis highlights a slight but significant inverse relationship between increased food intake and subjective social status: the higher we climb on the self-reported social ladder, the lower the percentage of respondents who increased their nutritional intake, substituted progressively by responses signaling no quantity variation (for reasons of space, these and some other data are not shown in the text. Interested readers can request them from the authors.). 
Table 4. Relation between change in quantity of food consumed daily and weight variation during the lockdown.

\begin{tabular}{|c|c|c|c|c|c|}
\hline \multirow{2}{*}{ Body Weight Variation during the Lockdown } & & \multicolumn{4}{|c|}{ Change in Quantity of Food Consumed during the Lockdown } \\
\hline & & Less Quantity & Same Quantity as Usual & More Quantity & Total \\
\hline Lost more than $3 \mathrm{~kg}$ & $\begin{array}{c}\text { Count } \\
\%\end{array}$ & $\begin{array}{c}60 \\
67.4 \%\end{array}$ & $\begin{array}{l}28 \\
31.5 \%\end{array}$ & $1 \%$ & $\begin{array}{c}89 \\
100 \%\end{array}$ \\
\hline Lost between 1 and $3 \mathrm{~kg}$ & $\begin{array}{c}\text { Count } \\
\%\end{array}$ & $\begin{array}{c}158 \\
42.8 \%\end{array}$ & $\begin{array}{c}161 \\
43.6 \%\end{array}$ & $\begin{array}{c}50 \\
13.6 \%\end{array}$ & $\begin{array}{r}369 \\
100 \%\end{array}$ \\
\hline No weight variation & $\underset{\%}{\text { Count }}$ & $\begin{array}{c}93 \\
11.3 \%\end{array}$ & $\begin{array}{c}559 \\
68.1 \%\end{array}$ & $\begin{array}{c}169 \\
20.6 \%\end{array}$ & $\begin{array}{c}821 \\
100 \%\end{array}$ \\
\hline Gained between 1 and $3 \mathrm{~kg}$ & $\begin{array}{c}\text { Count } \\
\%\end{array}$ & $\begin{array}{c}24 \\
3.2 \%\end{array}$ & $\begin{array}{c}225 \\
30.4 \%\end{array}$ & $\begin{array}{c}492 \\
66.4 \%\end{array}$ & $\begin{array}{c}741 \\
100 \%\end{array}$ \\
\hline Gained more than $3 \mathrm{~kg}$ & $\underset{\%}{\text { Count }}$ & $\begin{array}{c}3 \\
3.0 \%\end{array}$ & $\begin{array}{c}9 \\
9.1 \%\end{array}$ & $\begin{array}{c}87 \\
87.9 \%\end{array}$ & $\begin{array}{c}99 \\
100 \%\end{array}$ \\
\hline Total & $\underset{\%}{\text { Count }}$ & $\begin{array}{c}338 \\
16.0 \%\end{array}$ & $\begin{array}{c}982 \\
46.3 \%\end{array}$ & $\begin{array}{c}799 \\
37.7 \%\end{array}$ & $\begin{array}{c}2119 \\
100 \%\end{array}$ \\
\hline
\end{tabular}

Chi-squared test results: $\chi^{2}=950.65 ; p$-value $<0.0001$.

Such variations in nutritional regime seem to have had a powerful effect on the body weight of survey participants. The marginal column of Table 4 displays the weight variation in the sample. After almost three months of home isolation, only 821 respondents (corresponding to $38.7 \%$ of the sample) had indeed maintained their weight. Furthermore, by breaking down the figure it is possible to highlight how the lockdown lifestyle had a different impact on the various age groups surveyed. In fact, in addition to a fundamental assessment of the generalized strong impact of lockdown on body weight management, we found a more pronounced tendency to gain weight in older individuals with respect to younger individuals (For reasons of space, these and some other data are not shown in the text. Interested readers can request them from the authors.). Similarly, weight gain appears to be associated with the negative effects of the pandemic on household finances (i.e., higher-than-average ratios of weight gain affect those who suffered economically due to the COVID-19 outbreak) (For reasons of space, these and some other data are not shown in the text. Interested readers can request them from the authors.). However, the dimension that is most clearly and directly related to weight gain is the aforementioned increase in the quantity of food consumed. Unsurprisingly enough, the association between the adoption of a richer diet and weight gain during the lockdown is verified in our sample, as Table 4 demonstrates. The same cannot be said for diet variety, whose transformation, in both directions, is instead hardly linkable to body weight variation.

In order to delve more deeply into the transformations that diets underwent during the lockdown, respondents were asked to indicate the change in their consumption frequency of eleven food groups (As mentioned in Section 3.2, we derived and adapted this question's items from the EATLancet Commission's guidelines about healthy-sustainable diets [24]). Table 5 collects the full list, the possible answer modalities and the respective aggregated results. In the context of a widespread renovation of daily food habits characterized by a generalized increase in consumption, the observation that, for most food groups, there is a larger proportion of respondents who indicated a higher consumption frequency than of those who declared a lower frequency is not unexpected. In general terms, then, it is possible to deduce that the lockdown caused a major disruption in daily food routines, generating a tendency towards greater consumption of a wide variety of foods.

However, a closer look at the results reveals how certain food groups have been favored over others in the timeframe investigated. Among these, sweets and desserts, vegetable and carb dishes recorded the highest percentages of consumption increase, since they were eaten more frequently than usual by, respectively, $47 \%, 32.5 \%$, and $30.2 \%$ of the sample. Other foods privileged by lockdown eaters belong to the categories of fresh fruit $(27.5 \%$ consumed it more frequently than pre-lockdown), legumes $(23.1 \%)$ and dairy $(21.9 \%)$. Interestingly, meat does not seem to have played a leading role in lockdown diets. Despite the overarching tendency pointing towards increased variety and quantity of food consumption, the proportion of respondents who actually reduced consumption frequency of meat-based dishes $(15.5 \%)$ is slightly higher than that of those who consumed meat more frequently (14.7\%). A trend of reduction is also highlighted in the cases of sugary beverages (sodas and juices) and alcoholic drinks, most likely linked to the supervened impossibility 
of attending social gatherings and/or celebrations. Nevertheless, it is important to notice that $19.4 \%$ of the sample-a significant proportion-increased their alcohol consumption while under lockdown.

Table 5. Effect of the lockdown on consumption frequency of eleven food groups.

\begin{tabular}{|c|c|c|c|c|c|}
\hline \multicolumn{6}{|c|}{$\begin{array}{c}\text { In Comparison to Your 'Ordinary' Life Habits, How Often Have You Consumed the Following Dishes and Foods } \\
\text { during the Lockdown? }\end{array}$} \\
\hline Food Groups & Never & Less Frequently & As Usual & More Frequently & Total \\
\hline $\begin{array}{c}\text { Carb-based dishes } \\
\text { (e.g., pasta, rice, polenta) }\end{array}$ & $0.8 \%$ & $8.1 \%$ & $60.8 \%$ & $30.2 \%$ & $100.0 \%$ \\
\hline $\begin{array}{l}\text { Meat-based dishes } \\
\text { (red and/or white) }\end{array}$ & $8.3 \%$ & $15.5 \%$ & $61.5 \%$ & $14.7 \%$ & $100.0 \%$ \\
\hline $\begin{array}{c}\text { Vegetable-based dishes } \\
\text { (e.g., soups, salads, sautéed) }\end{array}$ & $1.1 \%$ & $10.2 \%$ & $56.2 \%$ & $32.5 \%$ & $100.0 \%$ \\
\hline $\begin{array}{c}\text { Legumes } \\
\text { (e.g., beans, chickpeas, lentils) }\end{array}$ & $8.9 \%$ & $11.3 \%$ & $56.7 \%$ & $23.1 \%$ & $100.0 \%$ \\
\hline $\begin{array}{c}\text { Whole-grain cereals } \\
\text { (e.g., whole-grain pasta, barley, farro) }\end{array}$ & $14.9 \%$ & $11.5 \%$ & $59.7 \%$ & $14.0 \%$ & $100.0 \%$ \\
\hline $\begin{array}{l}\text { Nuts and oily seeds } \\
\text { (e.g., sesame, pumpkin, chia) }\end{array}$ & $21.2 \%$ & $15.2 \%$ & $48.6 \%$ & $15.1 \%$ & $100.0 \%$ \\
\hline Dairy products & $6.0 \%$ & $10.8 \%$ & $61.3 \%$ & $21.9 \%$ & $100.0 \%$ \\
\hline $\begin{array}{c}\text { Sweets and desserts } \\
\text { (e.g., cookies, chocolate, cakes) }\end{array}$ & $4.2 \%$ & $14.4 \%$ & $34.4 \%$ & $47.0 \%$ & $100.0 \%$ \\
\hline Fresh fruit & $3.0 \%$ & $10.4 \%$ & $59.2 \%$ & $27.5 \%$ & $100.0 \%$ \\
\hline $\begin{array}{l}\text { Sugary beverages } \\
\text { (e.g., sodas, fruit juices) }\end{array}$ & $52.4 \%$ & $12.3 \%$ & $25.6 \%$ & $9.7 \%$ & $100.0 \%$ \\
\hline Alcoholic beverages & $26.6 \%$ & $24.0 \%$ & $29.9 \%$ & $19.4 \%$ & $100.0 \%$ \\
\hline
\end{tabular}

In sum, the lockdown seems to have had a double effect on diets: on the one hand, it spurred the consumption of ingredients typical of the Mediterranean diet (vegetables, legumes, fruit) and also deeply associated with traditional patterns of cooking and eating in Italy; on the other, it underscored the 'comforting' effect of certain foods, which brought many people to indulge, in our case, in pasta, sweets and dairy, perhaps in an attempt to cope with boredom and/or other negative subjective consequences of social confinement.

\subsection{Cooking Habits}

This renovated preference for 'basic' ingredients (e.g., pasta, fresh vegetables, legumes) underlines a concurrent and intertwined transformation: that of cooking habits. As has been anecdotally evident in Italy (and many other countries) since the very beginning of the lockdown, once in home confinement people began to cook with a much higher frequency and dedication than they had in their 'normal' lives, and in doing so arguably re-adopted traditional home-cooking styles (e.g., the stock shortage of home-baking staples (such as flour, yeast, etc.) that shortly followed the introduction of lockdown measures was extensively reported in the news.). In our study, this phenomenon is unmistakably confirmed. The vast majority of our respondents $(62.9 \%)$, in fact, reported having cooked more frequently during the lockdown-even much more frequently for $30.9 \%$-in comparison to their ordinary lives. Conversely, the figure of those who cooked less frequently than usual amounts to just $6.3 \%$. Table 6 collects this information.

The evidence of a re-discovery of home-cooking, though, is not limited to cooking frequency tout court. Indeed, as shown in Table 7, the types of kitchen activity performed reveal a tendency to venture into more elaborate cooking, to which greater time and attention are dedicated. To exemplify, we found that $45.6 \%$ of the sample engaged in the preparation of dishes from scratch more often, employing exclusively fresh raw materials (as opposed to ready-made and/or partially processed ingredients). Similarly, recipes that require more than $30 \mathrm{~min}$ of preparation were made more frequently by $56.3 \%$, while, by 
contrast, the consumption of convenience and quick-to-prepare meals dropped in frequency for $50.6 \%$ of the sample.

Table 6. Effect of the lockdown on the frequency of cooking.

\begin{tabular}{ccc}
\hline \multicolumn{3}{c}{ How Frequently Did You Cook during the Lockdown? } \\
\hline & Frequency & \% \\
\hline Never, others cooked for me & 205 & 9.0 \\
A lot less than usual & 75 & 3.3 \\
Slightly less than usual & 68 & 3.0 \\
As usual, the lockdown had no impact & 496 & 21.8 \\
Slightly more than usual & 730 & 32.0 \\
A lot more than usual & 705 & 30.9 \\
\hline Total & 2279 & 100 \\
\hline
\end{tabular}

Table 7. Lockdown effect on three cooking- and eating-related practices.

\begin{tabular}{|c|c|c|c|c|c|}
\hline \multicolumn{6}{|c|}{ In Comparison to Your 'Ordinary' Life Habits, How Often Have you Done the Following Activities during the Lockdown? } \\
\hline Activities & Never & Less Frequently & As Usual & More Frequently & Total \\
\hline $\begin{array}{l}\text { Cooked meals from scratch, using } \\
\text { only fresh raw materials (i.e., without } \\
\text { using ready-made or } \\
\text { pre-processed ingredients) }\end{array}$ & $6.1 \%$ & $4.3 \%$ & $44.0 \%$ & $45.6 \%$ & $100.0 \%$ \\
\hline $\begin{array}{c}\text { Cooked recipes that require more } \\
\text { than } 30 \text { min of preparation }\end{array}$ & $5.5 \%$ & $3.9 \%$ & $34.2 \%$ & $56.4 \%$ & $100.0 \%$ \\
\hline $\begin{array}{l}\text { Consumed quick dishes, which take } \\
\text { little time to prepare }\end{array}$ & - & $50.6 \%$ & $37.4 \%$ & $12.0 \%$ & $100.0 \%$ \\
\hline
\end{tabular}

Undoubtedly, such a cooking revival is partly motivated by the fact that staying at home was compulsory and access to external food sources was severely restricted. Individuals, therefore, were forced to cook most meals at home to feed their families. Nonetheless, the hypothesis that this additional homemaking burden would be received by most people with discomfort-especially in light of the widespread habit of buying lunch away from home due to working or schooling necessities-was not verified. On the contrary, our study detected an overwhelming appreciation of the time spent cooking during the lockdown, transversally affirmed with no regard to education, wealth or area of residence. In fact, when required to express the degree to which they enjoyed cooking while in home confinement, $35.4 \%$ of respondents judged the lived activity as quite pleasurable and $32.2 \%$ as very pleasurable, whereas only $9.4 \%$ found it either moderately or strongly tiresome. These results are displayed in the marginal row of Table 8 .

Despite this general tendency pointing towards a high level of enjoyment, some socio-demographic differences can be observed in our sample. These seem to connect to two dimensions. One is linked to age, with which a negative relationship is highlighted. With the exception of Baby Boomers, who reported noteworthy enthusiasm about cooking, younger generations showed the highest degrees of appreciation. In particular, as illustrated in Table 8, the proportion of respondents who lived lockdown cooking as a 'very pleasurable' experience manifestly decreases as we move up the generational scale. Once again, young people prove to be the protagonists of lockdown-induced transformations, whereby they were more deeply affected than their older counterparts.

A second dimension links cooking enjoyment to sociability. Our findings reveal that singles score lower in the appreciation of cooking versus people who spent the lockdown with their families. In addition, the pleasure derived from the preparation of food appears to go hand in hand with having lived cooking as a social experience: in fact, those who found themselves cooking with other members of the family more often than usual are also those who declared the greatest satisfaction. These findings are reported in Table 9. 
Table 8. Enjoyment derived from cooking under lockdown and its relation to age of respondents.

\begin{tabular}{|c|c|c|c|c|c|c|c|}
\hline \multirow[b]{2}{*}{ Generational Cohort } & & \multicolumn{6}{|c|}{$\begin{array}{c}\text { How Would You Describe Your Experience of Cooking during the Lockdown, on a Scale from } \\
\text { Very Tiresome to Very Pleasurable? }\end{array}$} \\
\hline & & Very Tiresome & Quite Tiresome & $\begin{array}{l}\text { Neither Tiresome } \\
\text { Nor Pleasurable }\end{array}$ & Quite Pleasurable & Very Pleasurable & Total \\
\hline \multirow{2}{*}{ Gen Z (14-24) } & Count & 4 & 15 & 65 & 135 & 151 & 370 \\
\hline & $\%$ & $1.0 \%$ & $4.1 \%$ & $17.6 \%$ & $36.5 \%$ & $40.8 \%$ & $100 \%$ \\
\hline \multirow{2}{*}{$\begin{array}{l}\text { Young Millennials } \\
(25-29)\end{array}$} & Count & 4 & 19 & 63 & 105 & 117 & 308 \\
\hline & $\%$ & $1.2 \%$ & $6.2 \%$ & $20.5 \%$ & $34.1 \%$ & $38.0 \%$ & $100 \%$ \\
\hline \multirow{2}{*}{$\begin{array}{l}\text { Adult Millennials } \\
\quad(30-40)\end{array}$} & Count & 8 & 40 & 128 & 192 & 163 & 531 \\
\hline & $\%$ & $1.5 \%$ & $7.5 \%$ & $24.1 \%$ & $36.2 \%$ & $30.7 \%$ & $100 \%$ \\
\hline \multirow{2}{*}{ Gen X (41-55) } & Count & 9 & 76 & 136 & 175 & 154 & 550 \\
\hline & $\%$ & $1.6 \%$ & $13.9 \%$ & $24.7 \%$ & $31.8 \%$ & $28.0 \%$ & $100 \%$ \\
\hline \multirow{2}{*}{ Baby Boomers (56-76) } & Count & 2 & 14 & 76 & 120 & 75 & 287 \\
\hline & $\%$ & $0.7 \%$ & $4.9 \%$ & $26.5 \%$ & $41.8 \%$ & $26.1 \%$ & $100 \%$ \\
\hline \multirow{2}{*}{ Elderly (over 77) } & Count & 0 & 2 & 5 & 2 & 2 & 11 \\
\hline & $\%$ & $0.0 \%$ & $18.1 \%$ & $45.5 \%$ & $18.2 \%$ & $18.2 \%$ & $100 \%$ \\
\hline \multirow[b]{2}{*}{ Total } & Count & 27 & 166 & 473 & 729 & 662 & 2057 \\
\hline & $\%$ & $1.3 \%$ & $8.1 \%$ & $23.0 \%$ & $35.4 \%$ & $32.2 \%$ & $100 \%$ \\
\hline
\end{tabular}

Chi-squared test results: $\chi^{2}=74.42 ; p$-value $<0.0001$.

Table 9. Relations between sociability dimensions and enjoyment of cooking during the lockdown.

\begin{tabular}{|c|c|c|c|c|c|c|c|}
\hline \multirow[b]{2}{*}{$\begin{array}{l}\text { Individuals Living } \\
\text { Together during the } \\
\text { Lockdown }\end{array}$} & & \multicolumn{6}{|c|}{$\begin{array}{c}\text { How Would You Describe Your Experience of Cooking during the Lockdown, on a Scale from } \\
\text { Very Tiresome to Very Pleasurable? }\end{array}$} \\
\hline & & Very Tiresome & Quite Tiresome & $\begin{array}{l}\text { Neither Tiresome } \\
\text { Nor Pleasurable }\end{array}$ & Quite Pleasurable & Very Pleasurable & Total \\
\hline Singles & $\underset{\%}{\text { Count }}$ & $\begin{array}{l}3 \\
1.2 \%\end{array}$ & $\begin{array}{c}27 \\
10.5 \%\end{array}$ & $\begin{array}{c}85 \\
33.1 \%\end{array}$ & $\begin{array}{c}77 \\
30.0 \%\end{array}$ & $\begin{array}{c}65 \\
25.2 \%\end{array}$ & $\begin{array}{c}257 \\
100 \%\end{array}$ \\
\hline Couples & $\underset{\%}{\text { Count }}$ & $\begin{array}{c}7 \\
1.0 \%\end{array}$ & $\begin{array}{c}45 \\
6.7 \% \\
\end{array}$ & $\begin{array}{c}134 \\
20.1 \%\end{array}$ & $\begin{array}{c}252 \\
37.8 \%\end{array}$ & $\begin{array}{c}229 \\
34.4 \%\end{array}$ & $\begin{array}{c}667 \\
100 \%\end{array}$ \\
\hline 3 people & $\underset{\%}{\text { Count }}$ & $\begin{array}{c}10 \\
2.1 \%\end{array}$ & $\begin{array}{c}32 \\
6.7 \%\end{array}$ & $\begin{array}{c}107 \\
22.3 \%\end{array}$ & $\begin{array}{c}173 \\
36.1 \%\end{array}$ & $\begin{array}{c}157 \\
32.8 \%\end{array}$ & $\begin{array}{c}479 \\
100 \%\end{array}$ \\
\hline 4-5 people & $\underset{\%}{\text { Count }}$ & $\begin{array}{c}7 \\
1.2 \%\end{array}$ & $\begin{array}{c}56 \\
9.6 \%\end{array}$ & $\begin{array}{c}134 \\
23.0 \%\end{array}$ & $\begin{array}{c}197 \\
33.9 \%\end{array}$ & $\begin{array}{c}188 \\
32.3 \%\end{array}$ & $\begin{array}{c}582 \\
100 \%\end{array}$ \\
\hline 6 people or more & $\underset{\%}{\text { Count }}$ & $\begin{array}{c}0 \\
0.0 \%\end{array}$ & $\begin{array}{c}4 \\
10.0 \%\end{array}$ & $\begin{array}{c}6 \\
15.0 \%\end{array}$ & $\begin{array}{c}21 \\
52.5 \%\end{array}$ & $\begin{array}{c}9 \\
22.5 \%\end{array}$ & $\begin{array}{c}40 \\
100 \%\end{array}$ \\
\hline Total & $\underset{\%}{\text { Count }}$ & $\begin{array}{c}27 \\
1.3 \%\end{array}$ & $\begin{array}{c}164 \\
8.1 \%\end{array}$ & $\begin{array}{c}466 \\
23.0 \%\end{array}$ & $\begin{array}{c}720 \\
35.6 \%\end{array}$ & $\begin{array}{c}648 \\
32.0 \%\end{array}$ & $\begin{array}{l}2025 \\
100 \%\end{array}$ \\
\hline $\begin{array}{c}\text { How frequently have you } \\
\text { cooked not alone, but } \\
\text { together with other famil } \\
\text { members? }\end{array}$ & & & & & & & \\
\hline Never & $\underset{\%}{\text { Count }}$ & $\begin{array}{c}6 \\
1.5 \%\end{array}$ & $\begin{array}{c}39 \\
9.9 \%\end{array}$ & $\begin{array}{c}139 \\
35.4 \%\end{array}$ & $\begin{array}{c}114 \\
29.0 \%\end{array}$ & $\begin{array}{c}95 \\
24.2 \%\end{array}$ & $\begin{array}{c}393 \\
100 \%\end{array}$ \\
\hline Less often than usual & $\underset{\%}{\text { Count }}$ & $\begin{array}{c}5 \\
3.8 \%\end{array}$ & $\begin{array}{c}16 \\
12.0 \%\end{array}$ & $\begin{array}{c}29 \\
21.8 \%\end{array}$ & $\begin{array}{c}42 \\
31.6 \%\end{array}$ & $\begin{array}{c}41 \\
30.8 \%\end{array}$ & $\begin{array}{c}133 \\
100 \%\end{array}$ \\
\hline As often as usual & $\underset{\%}{\text { Count }}$ & $\begin{array}{c}10 \\
1.6 \%\end{array}$ & $\begin{array}{c}44 \\
7.2 \%\end{array}$ & $\begin{array}{c}157 \\
25.9 \%\end{array}$ & $\begin{array}{c}211 \\
34.8 \%\end{array}$ & $\begin{array}{c}185 \\
30.5 \%\end{array}$ & $\begin{array}{c}607 \\
100 \%\end{array}$ \\
\hline More often than usual & $\underset{\%}{\text { Count }}$ & $\begin{array}{c}6 \\
0.6 \%\end{array}$ & $\begin{array}{c}67 \\
7.3 \%\end{array}$ & $\begin{array}{c}148 \\
16.0 \%\end{array}$ & $\begin{array}{c}362 \\
39.2 \%\end{array}$ & $\begin{array}{c}341 \\
36.9 \%\end{array}$ & $\begin{array}{c}924 \\
100 \%\end{array}$ \\
\hline Total & $\underset{\%}{\text { Count }}$ & $\begin{array}{c}27 \\
1.3 \%\end{array}$ & $\begin{array}{c}166 \\
8.1 \%\end{array}$ & $\begin{array}{c}473 \\
23.0 \%\end{array}$ & $\begin{array}{c}729 \\
35.4 \%\end{array}$ & $\begin{array}{c}662 \\
32.2 \%\end{array}$ & $\begin{array}{c}2057 \\
100 \%\end{array}$ \\
\hline
\end{tabular}

${ }^{*}$ Chi-squared test result: $\chi^{2}=37.40 ; p$-value $=0.002 *$ Chi-squared test result: $\chi^{2}=87.07 ; p$-value $<0.0001$.

\subsection{Factors Underlying a Healthy-Sustainable Transition}

Within this frame of modifications to household-level food practices, we compared the mean scores of the HST index for various surveyed dimensions to highlight the factors that underlie the transition towards a more healthy-sustainable diet. We found a series of illustrative relations connected to four individual spheres, namely: (a) socio-demographic differences; (b) eating and cooking patterns; (c) food purchasing behaviors; and (d) differences in attitudes towards food during the COVID-19 emergency. ANOVA tests were run for all analyzed relations; those displayed in the present sections are all statistically significant ( $p$-value $<0.05)$, whereas non-significant relations are omitted.

Table 10 explores the socio-demographic dimension. It shows that only individuals under 29 years of age and baby boomers (56-76) have a positive mean for the HST index, i.e., only these specific age groups have increased, on average, the healthiness and sustainability of their diets as an effect of the lockdown. In addition, the HST index results as being related to subjective socio-economic well-being (only participants who reported at least seven out of 10 on the MacArthur scale have positive means) and to working conditions during the lockdown: only people who worked from home have positive means; conversely essential 
workers are attributed the lowest scores. This underscores the importance of time allowance as a determining factor for introducing more HS consumption patterns into everyday life while, concurrently, highlighting the undermining potential of work- and socio-economicposition-related stressors, such as precariousness, uncertainty and economic dissatisfaction. Lastly, a clear relation is found between weight variation and HST index scores. Weight maintenance and weight loss are associated to positive values, signaling the fact that, during a lockdown connoted by a general increase in food consumption, those who were able to properly manage their weight have likely adopted a better diet.

Table 10. Means comparison and ANOVA test for the HST index with socio-demographic variables.

\begin{tabular}{|c|c|c|c|c|}
\hline & \multicolumn{4}{|c|}{ Healthy-Sustainable Transition Index } \\
\hline & $N$ & Mean & Std. Dev. & $p$-Value \\
\hline Generational Cohort & & & & 0.018 \\
\hline Gen Z (14-24) & 433 & 0.123 & 1.044 & \\
\hline Young Millennials (25-29) & 348 & 0.035 & 0.971 & \\
\hline Adult Millennials (30-40) & 570 & -0.073 & 1.034 & \\
\hline Gen X (41-55) & 604 & -0.067 & 1.012 & \\
\hline Baby Boomers (56-76) & 321 & 0.054 & 0.878 & \\
\hline Elderly (over 77) & 12 & -0.043 & 0.549 & \\
\hline $\begin{array}{c}\text { Subjective social status } \\
\text { (MacArthur scale from } 1 \text { to 10) }\end{array}$ & & & & 0.040 \\
\hline 4 or less & 257 & -0.063 & 1.021 & \\
\hline 5 & 415 & -0.022 & 0.985 & \\
\hline 6 & 595 & -0.076 & 0.979 & \\
\hline 7 & 720 & 0.070 & 1.027 & \\
\hline 8 or more & 292 & 0.079 & 0.969 & \\
\hline Working condition under lockdown & & & & 0.021 \\
\hline Working from home (always or most days) & 1369 & 0.037 & 1.019 & \\
\hline Not working (on leave, unemployed, etc.) & 265 & -0.045 & 1.054 & \\
\hline Essential sector (working as usual) & 183 & -0.200 & 0.857 & \\
\hline Other (students, retired, or unspecified) & 471 & -0.004 & 0.957 & \\
\hline Body weight variation during lockdown & & & & 0.000 \\
\hline Lost more than $3 \mathrm{~kg}$ & 89 & 0.862 & 1.191 & \\
\hline Lost between 1 and $3 \mathrm{~kg}$ & 369 & 0.391 & 0.976 & \\
\hline No weight variation & 821 & 0.116 & 0.850 & \\
\hline Gained between 1 and $3 \mathrm{~kg}$ & 741 & -0.312 & 0.981 & \\
\hline Gained more than $3 \mathrm{~kg}$ & 99 & -0.730 & 0.923 & \\
\hline
\end{tabular}

The HST index is useful for evaluating the health and environmental implications of the renewed eating and cooking behaviors adopted by individuals during the lockdown (Table 11). In terms of eating habits, positive average scores are associated with increased diet variety, stable or reduced daily food intake, increased consumption of light and healthy dishes, and reduced consumption of quick convenience meals. In the kitchen, instead, having cooked more often than usual and having enjoyed it (two variables that, in turn, are strongly associated with each other) predict a healthier and more sustainable turn of consumption patterns. Interest and dedication to food, therefore, emerge as crucial factors in prompting not only healthier, but also more environmentally friendly nutritional choices.

The comparison of index means with a set of variables that illustrate the change induced by the lockdown on food purchasing habits provides interesting insights (Table 12). A clear distinction, in terms of HS transition, emerges between industrial and localitybound products. An increased purchasing frequency of packaged or ready-made industrial foods is indeed linked to a reduction in the HS quality of diets. Contrarily, the purchases of locally-sourced foods or products with an identifiable national origin show a direct relation with positive index scores. Home deliveries, a procurement option which boomed during the lockdown period, are invested with a (slight) beneficial effect on the HST index only when the products purchased are fresh and/or processed ingredients (e.g., grocery). 
Instead, in the case of ready-to-eat meals (e.g., from restaurants), deliveries appear to have a negative impact on the HS transition.

Table 11. Means comparison and ANOVA test for the HST index with eating and cooking variables.

\begin{tabular}{|c|c|c|c|c|}
\hline & \multicolumn{4}{|c|}{ Healthy-Sustainable Transition Index } \\
\hline & $N$ & Mean & Std. Dev. & $p$-Value \\
\hline Quantity of food consumed during the lockdown & & & & 0.000 \\
\hline Less than usual & 371 & 0.608 & 1.073 & \\
\hline The same quantity as usual & 1051 & 0.152 & 0.796 & \\
\hline More than usual & 866 & -0.446 & 0.998 & \\
\hline Variety of the diet followed during the lockdown & & & & 0.000 \\
\hline A more monotonous diet & 284 & -0.451 & 1.220 & \\
\hline The same diet as usual & 900 & -0.010 & 0.777 & \\
\hline A more varied diet & 1104 & 0.124 & 1.064 & \\
\hline $\begin{array}{l}\text { Frequency of consumption of light } \\
\text { and healthy dishes }\end{array}$ & & & & 0.000 \\
\hline Less often than usual & 427 & -0.797 & 0.960 & \\
\hline As often as usual & 1271 & -0.048 & 0.772 & \\
\hline More often than usual & 590 & 0.681 & 1.000 & \\
\hline $\begin{array}{c}\text { Frequency of consumption of quick dishes, which } \\
\text { take little time to prepare }\end{array}$ & & & & 0.001 \\
\hline Less often than usual & 1157 & 0.055 & 1.014 & \\
\hline As often as usual & 857 & -0.011 & 0.933 & \\
\hline More often than usual & 274 & -0.199 & 1.114 & \\
\hline Frequency of cooking during the lockdown & & & & 0.044 \\
\hline Never, others cooked for me & 205 & -0.053 & 0.984 & \\
\hline A lot less than usual & 75 & -0.327 & 1.089 & \\
\hline Slightly less than usual & 68 & -0.111 & 1.153 & \\
\hline As usual, the lockdown had no impact & 496 & -0.014 & 0.851 & \\
\hline Slightly more than usual & 730 & 0.031 & 0.942 & \\
\hline A lot more than usual & 705 & 0.041 & 1.125 & \\
\hline $\begin{array}{l}\text { Enjoyment of cooking during the lockdown } \\
\text { (on a scale from very tiresome to very pleasurable) }\end{array}$ & & & & 0.000 \\
\hline Very tiresome & 27 & -0.407 & 1.190 & \\
\hline Quite tiresome & 166 & -0.277 & 1.058 & \\
\hline Neither tiresome nor pleasurable & 473 & -0.097 & 0.920 & \\
\hline Quite pleasurable & 729 & 0.061 & 0.989 & \\
\hline Very pleasurable & 662 & 0.097 & 1.032 & \\
\hline
\end{tabular}

Connected to food purchases, and equally insightful, are the results of the analysis of a group of variables that intercept the transformation of some food-related attitudes and orientations brought about by the outbreak of the pandemic. The responses of individuals provide, in aggregate, evidence of a process of acknowledgment of the role food plays in daily life both at the individual and societal level, which we verified as being intertwined with an improvement in the healthiness and sustainability of daily nutrition (Table 13). In fact, respondents who claimed to agree with statements that imply a restored attention to the importance of food are also significantly inclined to follow a more HS diet. A similar association is detectable with food waste, which $82.6 \%$ of households declared having reduced during the lockdown. To the contrary, in some cases, fears of viral contamination have translated into food safety concerns, prompting individuals to purchase more packaged food ( $22.2 \%$ of the total, in our sample) and subsequently increase their consumption of plastic and other disposable materials. This behavior clearly goes against a HS transition and, in our analysis, combines negatively with the HTS Index. 
Table 12. Means comparison and ANOVA test for the HST index with food purchase variables.

\begin{tabular}{|c|c|c|c|c|}
\hline & \multicolumn{4}{|c|}{ Healthy-Sustainable Transition Index } \\
\hline & $N$ & Mean & Std. Dev. & $p$-Value \\
\hline $\begin{array}{l}\text { Purchase frequency of packaged industrial foods } \\
\text { (e.g., snacks, ready-made sauces, processed foods) }\end{array}$ & & & & 0.000 \\
\hline Never & 482 & 0.079 & 0.968 & \\
\hline Less often than usual & 484 & 0.388 & 1.070 & \\
\hline As often as usual & 927 & -0.059 & 0.880 & \\
\hline More often than usual & 252 & -0.663 & 0.969 & \\
\hline $\begin{array}{l}\text { Purchase frequency of industrial } \\
\text { ready-made meals } \\
\text { (e.g., frozen or refrigerated) }\end{array}$ & & & & 0.000 \\
\hline Never & 686 & 0.022 & 0.984 & \\
\hline Less often than usual & 497 & 0.217 & 1.085 & \\
\hline As often as usual & 767 & -0.071 & 0.898 & \\
\hline More often than usual & 195 & -0.324 & 1.097 & \\
\hline $\begin{array}{c}\text { Purchase frequency of Italian products } \\
\text { (you checked the origin) }\end{array}$ & & & & 0.001 \\
\hline Never & 50 & -0.270 & 0.892 & \\
\hline Less often than usual & 62 & -0.396 & 1.221 & \\
\hline As often as usual & 1642 & 0.002 & 0.951 & \\
\hline More often than usual & 391 & 0.103 & 1.149 & \\
\hline $\begin{array}{c}\text { Purchase frequency of local products } \\
\text { (i.e., produced in your area or bought directly from } \\
\text { the producer) }\end{array}$ & & & & 0.005 \\
\hline Never & 331 & -0.086 & 1.066 & \\
\hline Less often than usual & 292 & -0.126 & 1.099 & \\
\hline As often as usual & 1038 & 0.017 & 0.923 & \\
\hline More often than usual & 484 & 0.108 & 1.041 & \\
\hline $\begin{array}{l}\text { Frequency of home-delivery of grocery } \\
\text { (i.e., fresh and/or processed ingredients) }\end{array}$ & & & & 0.029 \\
\hline Never & 1208 & 0.031 & 1.001 & \\
\hline Less often than usual & 103 & -0.198 & 1.051 & \\
\hline As often as usual & 166 & -0.147 & 0.809 & \\
\hline More often than usual & 668 & 0.017 & 1.031 & \\
\hline $\begin{array}{c}\text { Frequency of home-delivery of ready-to-eat meals } \\
\text { (e.g., from restaurants, pizzerias, etc.) }\end{array}$ & & & & 0.002 \\
\hline Never & 991 & 0.072 & 0.940 & \\
\hline Less often than usual & 418 & 0.028 & 1.042 & \\
\hline As often as usual & 332 & -0.073 & 0.992 & \\
\hline More often than usual & 404 & -0.135 & 1.090 & \\
\hline
\end{tabular}


Table 13. Means comparison and ANOVA test for the HST index with attitudinal variables.

\begin{tabular}{|c|c|c|c|c|}
\hline & \multicolumn{4}{|c|}{ Healthy-Sustainable Transition Index } \\
\hline & $N$ & Mean & Std. Dev. & $p$-Value \\
\hline \multicolumn{5}{|l|}{$\begin{array}{c}\text { During the lockdown caused by the COVID-19 } \\
\text { emergency I have: }\end{array}$} \\
\hline Preferred buying packaged foods over loose ones & & & & 0.030 \\
\hline Disagree & 783 & 0.033 & 0.995 & \\
\hline Neither agree nor disagree & 848 & 0.034 & 0.981 & \\
\hline Agree & 467 & -0.106 & 1.037 & \\
\hline Realized how crucial food is for health & & & & 0.000 \\
\hline Disagree & 206 & -0.029 & 0.893 & \\
\hline Neither agree nor disagree & 1103 & -0.114 & 0.938 & \\
\hline Agree & 789 & 0.174 & 1.085 & \\
\hline $\begin{array}{l}\text { Reflected upon the importance of the Italian gastronomic } \\
\text { culture }\end{array}$ & & & & 0.000 \\
\hline Disagree & 489 & -0.153 & 0.940 & \\
\hline Neither agree nor disagree & 897 & 0.036 & 0.993 & \\
\hline Agree & 712 & 0.068 & 1.039 & \\
\hline $\begin{array}{l}\text { Realized that it is necessary to pay a fair price to } \\
\text { producers to have safe and healthy food }\end{array}$ & & & & 0.001 \\
\hline Disagree & 153 & -0.190 & 0.998 & \\
\hline Neither agree nor disagree & 831 & -0.060 & 0.992 & \\
\hline Agree & 1114 & 0.075 & 1.000 & \\
\hline $\begin{array}{c}\text { Chosen to consume better and safer products, even if } \\
\text { pricier }\end{array}$ & & & & 0.000 \\
\hline Disagree & 382 & -0.185 & 0.959 & \\
\hline Neither agree nor disagree & 860 & 0.031 & 0.967 & \\
\hline Agree & 856 & 0.058 & 1.041 & \\
\hline Reduced food waste at home & & & & 0.000 \\
\hline Disagree & 121 & -0.396 & 1.140 & \\
\hline Neither agree nor disagree & 243 & -0.224 & 0.946 & \\
\hline Agree & 1734 & 0.062 & 0.987 & \\
\hline
\end{tabular}

\section{Discussion}

The COVID-19 pandemic outbreak has provided worldwide exposure to the selfreinforcing interdependencies between inadequate nutritional behaviors, unsustainable production, lack of food safety and global trade chains [1]. Against this backdrop, the social distancing measures implemented to fight viral transmission have immediately left a notable mark on daily nutrition and food-related habits, thus enabling a timely scientific observation of the 'ruptures' that affected consolidated consumption paradigms in many localities of the world. Specifically, in our Italian case study the lockdown prompted widespread transformations in food procurement, preparation and consumption patterns and contributed to redefining some food-related behaviors and sensitivities. Due to the exceptionality of the event, it is difficult to foresee the prolonged effects of the pandemic and, in our case, whether the transformations our data suggest will be normalized into new routines. Nonetheless, efforts to describe the impact of the lockdown on diets and interpret emerging phenomena leading to more HS patterns are essential first steps to govern the future transition of consumption models.

\subsection{The Impact of the Lockdown on Diets}

Diets are chosen as empirical indicators of new routines for their immediate implications on human health. In line with a trend observed in many different localities over the same period-in fact shared among eaters from Italy [50], Spain [42], France [38], Poland [39,51], the UK [37], Palestine [52], and the United Arab Emirates [53]—daily quantities of food consumed (and therefore caloric intake) significantly increased during home confinement. At the same time, though, lockdown diets were characterized by more variety, 
and some ingredients found their way onto the table more often than others. Given the importance of dietary diversity for healthy nutrition [54], this outcome might embody a crucial element of distinction for the COVID-19 emergency: contrary to past crises, including the economic recession of the late 2000s [55], the current pandemic did not produce, at least in Italy, a disenfranchising effect on people's capabilities to follow a varied diet. Rather, for some segments of the population, it seemed to have created more favorable conditions for dietary improvement.

Lockdown food choices appear to be shaped by two main latent variables: one is 'mood', associated with the increased consumption of comforting foods, such as pasta, sweets and dairy, which are intended to alleviate the negative psychological consequences of confinement $[38,41]$; the other is linked to the preparation of meals at home and traditional Mediterranean eating patterns [56,57], which strongly rely on fresh plant-based ingredients (vegetables, fruit, legumes), often with a local or national origin. Conversely, a drop in consumption frequency was observed for products ascribed to the sphere of time constraint and convenience, such as industrially processed and ready-made foods. This datum, despite reasonable doubts concerning the eventual longevity of the trend it underlines, suggests a potential turnaround in consolidated unsustainable tendencies, such as the seemingly uninterrupted growth of semi-processed and 'fourth range' product segments in modern societies. Similarly, in contrast to various studies conducted in Europe [42,51], we found meat consumption-notoriously under 'special surveillance' for its enormous impact on both individual health and planetary sustainability [58] - to be slightly reduced.

This brings us to the core aim of our research, which was to assess the effect of the lockdown on diets by applying a lens that combines health and environmental sustainability. We contend, as already mentioned, that these two elements compose a binomial entity that ought to be operationalized and sought after in indissoluble conjunction, in pursuit of truly sustainable development for modern societies [24]. To do so, we evaluated the 'healthysustainable' quality of diets through the construction of the HST index. What emerged was a spectrum of healthy-sustainable transitions that does not allow the researcher to assess one net effect, instead rendering the variance of impacts of the pandemic outbreak on household daily food habits. In contrast with Battle-Bayer et al. [42], who found that most lockdown diets placed an additional burden on the environment, we highlighted that HS performances unfold on a gradient, which reveals that while for a part of the sample lockdown nutrition implied overeating and weight gain, a substantial section of the population instead improved the healthiness and sustainability of their daily nutritional patterns. For many individuals, then, the lockdown was a (forced) occasion to adopt a more HS diet.

\subsection{Levers for a Healthy-Sustainable Transition of Diets}

An analysis of the factors associated with a positive HS transition enables us to unveil some fundamental dynamics. Firstly, a positive transformation is linked directly to socioeconomic status and inversely to other related stressors, such as financial and/or job loss due to the pandemic. This relates to issues of affordability and access, highlighting the long-standing nexus between availability of social and economic capital and virtuous food choices [35]. Secondly, positive performances are directly correlated to an increase in frequency of the act of cooking. In fact, not only did an overwhelming majority of respondents cook more often during the studied period, but they also did it in the company of family members and reported having thoroughly enjoyed the experience. Perhaps facilitated by the profoundly identity-shaping cultural meaningfulness attributed to food and gastronomic tradition in Italy [59], the lockdown brought about a resurgence of homecooking which, in combination with increased time allowance, acted to revive a stronger daily life commitment to food (in general) and to cooking from scratch (in particular). This, in turn, accentuated households' focus on product seasonality, local procurement, and waste reduction. 
We frame this occurrence as a positive sign since, as our study demonstrates, the focus of individuals on the quality, provenance and materiality of food is correlated to more sustainable consumption, even in times of crisis. In fact, our data suggest that the emergency also had an effect on the cultural representation of food and the sociality that revolves around it. It kindled, among large portions of the public, a reflection about the role of food in society, both at the individual and systemic level. Whether for its entanglements with health, culture and societal well-being, or for the need to safeguard its wholesomeness, food seems to have emerged from the first, troubled, months of the pandemic with an elevated value, that is, a more widespread recognition of its centrality to human life. This embodies an opportunity to put on the right footing a process of transformation of foodrelated sensitivities that is already in motion [60], and that the pandemic, if anything, is helping to diffuse and potentially accelerate.

Connected to this, the last reflection our data enabled accounts for generational differences detected in the sample. As other studies have also pointed out [10,56,61], young people (under 29 years old) compose the demographic segment whose food habits and behaviors have been most deeply affected by confinement measures. Whether entailing an increase or decrease in the frequency of specific behaviors, the disruptions caused by the pandemic appear to have impacted the daily life of young individuals more strongly than that of their older counterparts. At the same time, though, this cohort's reaction to lockdown restrictions was founded on a more pronounced sustainable 'turn' of food-related choices and behaviors: they reported enthusiasm about cooking, which they enjoyed as a shared activity with family members, and as also noted in other Italian research $[8,62]$, improved their diet by privileging raw fresh ingredients at the expense of industriallyprocessed ones.

The higher average scores of young people on the HST index suggest that they must be addressed as the true agents of change, not only because their preferences will soon shape the mainstream consumption environment, but also because their behavior during the lockdown demonstrates that the ground for a sustainable transformation of consumer paradigms is already set, and that the crisis can represent an opportunity to trigger the materialization of a new vision. Young people have introjected, more than others, the urgency of developing an attitude of environmental and resource conservation: the way they reacted to social confinement confirms that the cultural and economic process necessary to establish more sustainable food consumption models must, therefore, be anchored to the prerogatives, expectations, expression modalities, and communication tools (re: social media) of young generations.

\section{Conclusions}

The outbreak of the COVID-19 pandemic caused major perturbations in the food environment (defined as the physical, economic, political, and socio-cultural context in which consumers engage with the food system to make decisions about acquiring, preparing, and consuming food [63].) of many localities of the world, which were further exacerbated by the introduction of social isolation and business shutdown measures intended to slow the transmission of the virus. This research investigated the profiles of the healthiness and sustainability of the transformations that occurred in the daily nutritional choices and behaviors of a large convenience sample of Italian households during the March-May 2020 general lockdown. For decades now, the food environment of European countries, as also officially noted by the EU [63], has failed to ensure easy and affordable access to healthy and sustainable options for all. The sudden and unexpected disruptions to the food sector, which simultaneously unfolded at the global and local levels, therefore represented fertile ground for studying individuals' reaction modes as well as the adaptations of their daily habits to the mutated circumstances in a Mediterranean context, in order to highlight latent trends and possible future food policy interventions to enhance health and sustainability.

Home confinement greatly affected the food behaviors of our respondents. Modifications unfolded along two lines. On the one hand, our findings exposed practices of 
overeating and excessive consumption of 'comfort' food motivated by a set of psychological stressors, expectedly correlated to quarantine and/or to the abundance of unhealthy temptations at home. Such a realization underscores the critical condition that might affect overweight and obese people, who are in turn more susceptible to long-term complications from COVID-19, especially in the face of the ongoing social contact restrictions that the sanitary situation might continue to necessitate.

On an opposite note, the COVID-19 crisis seemed to be an occasion for a large section of the population to rethink food and nutrition. The emergency abruptly accelerated the (already gestating) process of acknowledgement of the fragility of global, just-in-time food chains, as well as the detrimental and interconnected effects of human activity on global ecosystems. This cultural element combined with a much more practical one, i.e., the suddenly increased availability of time and mental resources to dedicate to learning about, reflecting on, choosing and preparing food, and brought about a resurgence of homecooking. During lockdown weeks, food was appreciated in its raw, fresh, seasonal, local and unprocessed form, (re-)gaining relevance not only as a pleasurable hobby (cooking as a leisure activity) but also as a cornerstone of pro-health behaviors and shared social practices. This led to an improvement in the healthiness and sustainability of diets-more prominently ascribed to the youth in our sample-which we measured and compared through the elaboration of the healthy-sustainable transition index.

Hence, the food perspective suggests a framing of the emergency we are currently experiencing as a call to awaken our conscience and address the unsustainability inherent in the dominant socio-economic paradigm. It provides the grounds for advancing a critique of modern life organization which, with the frenetic rhythms and invasive commodification it imposes-respectively-on people and goods, prevents individuals from interacting in a respectful way with the resources of the planet and, ultimately, exercising their right to access good, healthy, nutritious and environmentally-responsible food.

Relatedly, the pandemic embodies an opportunity to advance the sustainability agenda, in pursuit of the globally-evoked new Green Deal and, in Europe, along the lines of the Farm to Fork strategy of the EU, whose overarching goal is to create a "favorable food environment that makes it easier to choose healthy and sustainable diets" [63]. The seeds of change we have detected through our study have the potential, if properly supported, to contribute to the achievement of several objectives of the European program, namely stimulating the food industry and retail sector to increase the availability and affordability of healthy-sustainable food options, enhancing the resilience of regional and local food systems by fostering shorter supply chains, empowering consumers to make informed food choices by strengthening their food and nutrition education, and strongly reducing food waste at the retail and household level.

The evidence gathered by this research does not allow for bullet-proof generalizations, though it does suggest that while the trajectories towards such a transition are likely already plotted, adequate support from cultural, political and economic institutions will be necessary to create the conditions for sustainable food production and consumption to take hold as the 'new' normal in the post-pandemic era. This is a subject for future research, one that will verify whether the discussed changes in daily life resource allocation and food-related behaviors will become structural once the tidal wave of the pandemic recedes.

At the moment, however, the lessons that can be drawn from the examination of nutrition under lockdown allow us to delineate four suggested areas of intervention (we thank Deschasaux-Tanguy and colleagues [10], from whom we drew inspiration in naming the four areas of intervention). The first is time, which the lockdown demonstrated to be a key variable in the effective improvement of nutrition. A much-needed re-assessment of work-life balance will endow individuals with the adequate time to devote to food selection and preparation. The second area regards the provision to consumers of appropriate tools for recognizing and pursuing better nutrition: food knowledge, education, and access to healthy-sustainable food, both in its physical and economic sense, should therefore be promoted. Thirdly, interventions are needed to improve food supply at work, i.e., spur the 
establishment of a more favorable food environment in and around workplaces to make healthy and sustainable lunch-time habits as easy to follow at work as at home. Fourth, focus should be placed on local and short food supply chains in order to strengthen and disseminate the availability and affordability of sustainable food options. Lastly, we reckon that the key actors on whom to call to boost this great transformation are young people. Their dynamism, susceptibility to change, and environmentally friendly orientation have been expressed even during the harsh days of lockdown: their worldviews, dispositions, and attitudes are likely, if properly channeled, to bring about the paradigm shift in the consumption of food and environmental resources that the planet desperately needs.

Author Contributions: Statistical analysis, manuscript writing: R.M. and M.Z.; research conceptualization and design, data collection and analysis, manuscript conceptualization, discussion and review: R.M., M.Z., M.D., S.M., and M.L. All authors have read and agreed to the published version of the manuscript.

Funding: This research received no external funding.

Institutional Review Board Statement: The study was conducted according to the guidelines of the Declaration of Helsinki, and approved by the Ethics Committee of the Department of Psychology of the University of Milan-Bicocca (Protocol RM-2020-297, 13 May 2020).

Informed Consent Statement: Informed consent to the participation in the survey and data treatment was obtained from all subjects involved in the study.

Data Availability Statement: The dataset analyzed in the study was created by the authors and is publicly available at: https:/ / drive.google.com/file/d/1dJv_lF63uSusoEw4YRulEnMk9SBRqOvY / view? usp=sharing (accessed 13 May 2021).

Conflicts of Interest: The authors declare no conflict of interest.

\section{References}

1. Galimberti, A.; Cena, H.; Campone, L.; Ferri, E.; Dell'Agli, M.; Sangiovanni, E.; Belingheri, M.; Riva, M.A.; Casiraghi, M.; Labra, M. Rethinking Urban and Food Policies to Improve Citizens Safety After COVID-19 Pandemic. Front. Nutr. 2020, 7, 569542. [CrossRef] [PubMed]

2. GWI. Coronavirus Research-Multi-Market Research Wave 2-April 2020; Global Web Index: London, UK, 2020.

3. Navarro, P. In Lockdown: The Food Revolution. Available online: https://wearesocial.com/blog/2020/04/in-lockdown-thefood-revolution (accessed on 27 October 2020).

4. Brooks, S.K.; Webster, R.K.; Smith, L.E.; Woodland, L.; Wessely, S.; Greenberg, N.; Rubin, G.J. The psychological impact of quarantine and how to reduce it: Rapid review of the evidence. Lancet 2020, 395, 912-920. [CrossRef]

5. Mattioli, A.V.; Sciomer, S.; Cocchi, C.; Maffei, S.; Gallina, S. Quarantine during COVID-19 outbreak: Changes in diet and physical activity increase the risk of cardiovascular disease. Nutr. Metab. Cardiovasc. Dis. 2020, 30, 1409-1417. [CrossRef]

6. Muscogiuri, G.; Barrea, L.; Savastano, S.; Colao, A. Nutritional recommendations for CoVID-19 quarantine. Eur. J. Clin. Nutr. 2020, 74, 850-851. [CrossRef]

7. Ma, Y.; Ratnasabapathy, R.; Gardiner, J. Carbohydrate craving: Not everything is sweet. Curr. Opin. Clin. Nutr. Metab. Care 2017, 20, 261-265. [CrossRef]

8. Di Renzo, L.; Gualtieri, P.; Pivari, F.; Soldati, L.; Attinà, A.; Cinelli, G.; Leggeri, C.; Caparello, G.; Barrea, L.; Scerbo, F.; et al. Eating habits and lifestyle changes during COVID-19 lockdown: An Italian survey. J. Transl. Med. 2020, 18, 229. [CrossRef]

9. Naja, F.; Hamadeh, R. Nutrition amid the COVID-19 pandemic: A multi-level framework for action. Eur. J. Clin. Nutr. 2020, 74, 1117-1121. [CrossRef] [PubMed]

10. Deschasaux-Tanguy, M.; Druesne-Pecollo, N.; Esseddik, Y.; de Edelenyi, F.S.; Alles, B.; Andreeva, V.A.; Baudry, J.; Charreire, H.; Deschamps, V.; Egnell, M.; et al. Diet and physical activity during the COVID-19 lockdown period (March-May 2020): Results from the French NutriNet-Santé cohort study. MedRxiv 2020. [CrossRef]

11. Butler, M.J.; Barrientos, R.M. The impact of nutrition on COVID-19 susceptibility and long-term consequences. Brain Behav. Immun. 2020, 87, 53-54. [CrossRef]

12. Laviano, A.; Koverech, A.; Zanetti, M. Nutrition support in the time of SARS-CoV-2 (COVID-19). Nutrition 2020, 74, 110834. [CrossRef]

13. Cena, H.; Chieppa, M. Coronavirus Disease (COVID-19-SARS-CoV-2) and Nutrition: Is Infection in Italy Suggesting a Connection? Front. Immunol. 2020, 11, 944. [CrossRef]

14. Muscogiuri, G.; Pugliese, G.; Barrea, L.; Savastano, S.; Colao, A. Commentary: Obesity: The "Achilles heel" for COVID-19? Metabolism 2020, 108, 154251. [CrossRef] 
15. Rebelos, E.; Moriconi, D.; Virdis, A.; Taddei, S.; Foschi, D.; Nannipieri, M. Letter to the Editor: Importance of metabolic health in the era of COVID-19. Metabolism 2020, 108, 154247. [CrossRef]

16. FAO. World Livestock: Transforming the Livestock Sector through the Sustainable Development Goals; FAO: Rome, Italy, $2018 ;$ p. 222.

17. Shahidi, F. Does COVID-19 Affect Food Safety and Security? J. Food Bioact. 2020, 9, 1-3. [CrossRef]

18. Jones, K.E.; Patel, N.G.; Levy, M.A.; Storeygard, A.; Balk, D.; Gittleman, J.L.; Daszak, P. Global trends in emerging infectious diseases. Nat. Cell Biol. 2008, 451, 990-993. [CrossRef]

19. Morse, S.S. Factors in the Emergence of Infectious Diseases. Emerg. Infect. Dis. 1995, 1, 7-15. [CrossRef]

20. Volpato, G.; Fontefrancesco, M.F.; Gruppuso, P.; Zocchi, D.M.; Pieroni, A. Baby pangolins on my plate: Possible lessons to learn from the COVID-19 pandemic. J. Ethnobiol. Ethnomed. 2020, 16, 1-12. [CrossRef]

21. FAO; WHO. Sustainable Healthy Diets—Guiding Principles; Food and Agriculture Organization (FAO) and World Health Organization (WHO) of the United Nations: Rome, Italy, 2019.

22. Meybeck, A.; Gitz, V. Sustainable diets within sustainable food systems. Proc. Nutr. Soc. 2017, 76, 1-11. [CrossRef]

23. Riley, H.; Buttriss, J.L. A UK public health perspective: What is a healthy sustainable diet? Nutr. Bull. 2011, 36, 426-431. [CrossRef]

24. Willett, W.; Rockström, J.; Loken, B.; Springmann, M.; Lang, T.; Vermeulen, S.; Garnett, T.; Tilman, D.; DeClerck, F.; Wood, A.; et al. Food in the Anthropocene: The EAT-Lancet Commission on healthy diets from sustainable food systems. Lancet 2019, 393, 447-492. [CrossRef]

25. Davies, A.R. Toward a Sustainable Food System for the European Union: Insights from the Social Sciences. One Earth 2020, 3 , 27-31. [CrossRef]

26. Hakovirta, M.; Denuwara, N. How COVID-19 Redefines the Concept of Sustainability. Sustainability 2020, 12, 3727. [CrossRef]

27. Cohen, M.J. Does the COVID-19 outbreak mark the onset of a sustainable consumption transition? Sustain. Sci. Pract. Policy 2020, 16, 1-3. [CrossRef]

28. Ioannides, D.; Gyimóthy, S. The COVID-19 crisis as an opportunity for escaping the unsustainable global tourism path. Tour. Geogr. 2020, 22, 624-632. [CrossRef]

29. Majumdar, A.; Shaw, M.; Sinha, S.K. COVID-19 debunks the myth of socially sustainable supply chain: A case of the clothing industry in South Asian countries. Sustain. Prod. Consum. 2020, 24, 150-155. [CrossRef]

30. Oldekop, J.A.; Horner, R.; Hulme, D.; Adhikari, R.; Agarwal, B.; Alford, M.; Bakewell, O.; Banks, N.; Barrientos, S.; Bastia, T.; et al. COVID-19 and the case for global development. World Dev. 2020, 134, 105044. [CrossRef]

31. Sarkis, J.; Cohen, M.J.; Dewick, P.; Schröder, P. A brave new world: Lessons from the COVID-19 pandemic for transitioning to sustainable supply and production. Resour. Conserv. Recycl. 2020, 159, 104894. [CrossRef]

32. Pan, S.L.; Zhang, S. From fighting COVID-19 pandemic to tackling sustainable development goals: An opportunity for responsible information systems research. Int. J. Inf. Manag. 2020, 55, 102196. [CrossRef]

33. Capra, F. The COVID-19 pandemic: A systemic analysis. Agric. Hum. Values 2020, 37, 665-666. [CrossRef]

34. Bodenheimer, M.; Leidenberger, J. COVID-19 as a window of opportunity for sustainability transitions? Narratives and communication strategies beyond the pandemic. Sustain. Sci. Pract. Policy 2020, 16, 61-66. [CrossRef]

35. ASVIS. Politiche Per Fronteggiare la Crisi da COVID-19 e Realizzare l'Agenda 2030 Per lo Sviluppo Sostenibile; ASVIS-Alleanza Italiana per lo Sviluppo Sostenibile: Roma, Italy, 2020.

36. Özlem, A.; Mehmet, N. COVİD-19 Pandemi Kilitlenmesi Sürecinde Yeme Alışkanlıklarındaki Değişiklikler. ESTÜDAM Halk Sağlı̆̆ı Dergisi 2020, 5, 188-196. [CrossRef]

37. Robinson, E.; Boyland, E.; Chisholm, A.; Harrold, J.; Maloney, N.G.; Marty, L.; Mead, B.R.; Noonan, R.; Hardman, C.A. Obesity, eating behavior and physical activity during COVID-19 lockdown: A study of UK adults. Appetite 2021, 156, 104853. [CrossRef] [PubMed]

38. Marty, L.; de Lauzon-Guillain, B.; Labesse, M.; Nicklaus, S. Food choice motives and the nutritional quality of diet during the COVID-19 lockdown in France. Appetite 2021, 157, 105005. [CrossRef] [PubMed]

39. Górnicka, M.; Drywień, M.E.; Zielinska, M.A.; Hamułka, J. Dietary and Lifestyle Changes During COVID-19 and the Subsequent Lockdowns among Polish Adults: A Cross-Sectional Online Survey PLifeCOVID-19 Study. Nutrients 2020, $12,2324$. [CrossRef] [PubMed]

40. Fontefrancesco, M.F. (Ed.) Effetto Lockdown: Come Sono Cambiate le Abitudini Alimentari Degli Italiani Durante L'emergenza COVID-19; Università di Scienze Gastronomiche di Pollenzo: Bra-Pollenzo, Italy, 2020.

41. Laguna, L.; Fiszman, S.; Puerta, P.; Chaya, C.; Tárrega, A. The impact of COVID-19 lockdown on food priorities. Results from a preliminary study using social media and an online survey with Spanish consumers. Food Qual. Prefer. 2020, 86, 104028. [CrossRef]

42. Batlle-Bayer, L.; Aldaco, R.; Bala, A.; Puig, R.; Laso, J.; Margallo, M.; Vázquez-Rowe, I.; Antó, J.M.; Fullana-I-Palmer, P. Environmental and nutritional impacts of dietary changes in Spain during the COVID-19 lockdown. Sci. Total Environ. 2020, 748, 141410. [CrossRef]

43. Fricker, R.D.; Schonlau, M. Advantages and Disadvantages of Internet Research Surveys: Evidence from the Literature. Field Methods 2002, 14, 347-367. [CrossRef]

44. Adler, N.E.; Epel, E.S.; Castellazzo, G.; Ickovics, J.R. Relationship of subjective and objective social status with psychological and physiological functioning: Preliminary data in healthy, White women. Health Psychol. 2000, 19, 586-592. [CrossRef]

45. Linting, M.; Van Der Kooij, A. Nonlinear Principal Components Analysis With CATPCA: A Tutorial. J. Pers. Assess. 2012, 94, 12-25. [CrossRef] 
46. Linting, M.; Meulman, J.J.; Groenen, P.J.F.; Van Der Koojj, A.J. Nonlinear principal components analysis: Introduction and application. Psychol. Methods 2007, 12, 336-358. [CrossRef]

47. Meulman, J.J.; Van der Kooij, A.J.; Heiser, W.J. Principal components analysis with nonlinear optimal scaling transfor-mations for ordinal and nominal data. In The Sage Handbook of Quantitative Methodology for the Social Sciences; Kaplan, D., Ed.; Sage: London, UK, 2004; pp. 50-71.

48. Cronbach, L.J. Coefficient alpha and the internal structure of tests. Psychometrika 1951, 16, 297-334. [CrossRef]

49. Heiser, W.J.; Meulman, J.J. Homogeneity analysis: Exploring the distribution of variables and their nonlinear relationships. In Correspondence Analysis in the Social Sciences: Recent Developments and Applications; Greenacre, M., Blasius, J., Eds.; Academic Press: New York, NY, USA, 1992; pp. 179-209.

50. Scarmozzino, F.; Visioli, F. Covid-19 and the Subsequent Lockdown Modified Dietary Habits of Almost Half the Population in an Italian Sample. Foods 2020, 9, 675. [CrossRef] [PubMed]

51. Sidor, A.; Rzymski, P. Dietary Choices and Habits during COVID-19 Lockdown: Experience from Poland. Nutrients 2020, 12, 1657. [CrossRef]

52. Allabadi, H.; Dabis, J.; Aghabekian, V.; Khader, A.; Khammash, U. Impact of COVID-19 lockdown on dietary and lifestyle behaviours among adolescents in Palestine. Dyn. Hum. Health 2020, 7, 2170.

53. Ismail, L.C.; Osaili, T.M.; Mohamad, M.N.; Al Marzouqi, A.; Jarrar, A.H.; Abu Jamous, D.O.; Magriplis, E.; Ali, H.I.; Al Sabbah, H.; Hasan, H.; et al. Eating Habits and Lifestyle during COVID-19 Lockdown in the United Arab Emirates: A Cross-Sectional Study. Nutrients 2020, 12, 3314. [CrossRef]

54. Azadbakht, L.; Esmaillzadeh, A. Diet variety: A measure of nutritional adequacy and health. J. Qazvin Univ. Med. Sci. 2009, 13, 88-97.

55. Bonaccio, M.; Bes-Rastrollo, M.; De Gaetano, G.; Iacoviello, L. Challenges to the Mediterranean diet at a time of economic crisis. Nutr. Metab. Cardiovasc. Dis. 2016, 26, 1057-1063. [CrossRef] [PubMed]

56. Sánchez-Sánchez, E.; Ramírez-Vargas, G.; Avellaneda-López, Y.; Orellana-Pecino, J.I.; García-Marín, E.; Díaz-Jimenez, J. Eat-ing Habits and Physical Activity of the Spanish Population during the COVID-19 Pandemic Period. Nutrients 2020, 12, 2826. [CrossRef]

57. Rodríguez-Pérez, C.; Molina-Montes, E.; Verardo, V.; Artacho, R.; García-Villanova, B.; Guerra-Hernández, E.J.; Ruíz-López, M.D. Changes in Dietary Behaviours during the COVID-19 Outbreak Confinement in the Spanish COVIDiet Study. Nutrients 2020, 12, 1730. [CrossRef]

58. De Boer, J.; Schösler, H.; Aiking, H. "Meatless days" or "less but better"? Exploring strategies to adapt Western meat consumption to health and sustainability challenges. Appetite 2014, 76, 120-128. [CrossRef]

59. Scarpellini, E. A Tavola! Gli Italiani in 7 Pranzi; Laterza: Roma-Bari, Italy, 2014

60. Boons, F.; Burgess, M.; Ehgartner, U.; Hirth, S.; Hodson, M.; Holmes, H. Covid-19, Changing Social Practices and the Transi-tion to Sustainable Production and Consumption; Sustainable Consumption Institute: Manchester, UK, 2020; Version 1.0.

61. Poelman, M.P.; Gillebaart, M.; Schlinkert, C.; Dijkstra, S.C.; Derksen, E.; Mensink, F.; Hermans, R.C.; Aardening, P.; de Ridder, D.; de Vet, E. Eating behavior and food purchases during the COVID-19 lockdown: A cross-sectional study among adults in the Netherlands. Appetite 2021, 157, 105002. [CrossRef] [PubMed]

62. Principato, L.; Secondi, L.; Cicatiello, C.; Mattia, G. Caring more about food: The unexpected positive effect of the Covid-19 lockdown on household food management and waste. Socio-Econ. Plan Sci. 2020, 100953. [CrossRef]

63. EU. Farm to Fork Strategy. For a Fair, Healthy and Environmentally-Friendly Food System; European Commission: Brussels, Belgium, 2020. 